\title{
Affinity purification and characterization of a fibrinogen-binding protein complex which protects mice against lethal challenge with Streptococcus equi subsp. equi
}

\author{
Mary Meehan, ${ }^{1,2}$ Peter Nowlan ${ }^{3}$ and Peter Owen ${ }^{2}$ \\ Author for correspondence: Peter Owen. Tel: +35316081188 . Fax: +35 316799294. \\ e-mail: powen@tcd.ie
}

National Pharmaceutical Biotechnology Centre, BioResearch Ireland ${ }^{1}$, Department of Microbiology, Moyne Institute of Preventive Medicine2, and Bioresources Unit ${ }^{3}$, Trinity College, Dublin 2, Ireland

\begin{abstract}
Cell-wall-associated proteins from Streptococcus equi subsp. equi, the causative agent of strangles, were analysed with a view to identifying a potential protective antigen. Preparations of these proteins, isolated from mutanolysin extracts of cell walls, were shown to contain one major high- $M_{r}$ protein species (apparent $M_{r}, 220000$ and 550000 when analysed by SDS-PAGE and gel-filtration chromatography, respectively). The high- $M_{r}$ protein bound horse fibrinogen and was purified under non-denaturing conditions using fibrinogen affinity chromatography. The fibrinogen-binding protein (FgBP) reacted with serum taken from horses recovering from strangles and protected mice against lethal challenge from $S$. equi subsp. equi. The sequence of the corresponding gene ( $\mathrm{fbp}$ ) was determined and shown to encode a mature protein $\left(M_{r} 54597\right)$ with predicted coiled-coil structure. An FgBP truncate, lacking the C-terminal cell wall/membrane anchor domain, was overexpressed in and purified from Escherichia coli and was shown to behave in an analogous fashion to the wild-type product in terms of $M_{r}$ estimation, fibrinogen binding and seroreactivity.
\end{abstract}

Keywords: Streptococcus equi subsp. equi, fibrinogen-binding protein, protective antigen

\section{INTRODUCTION}

The group C streptococcus Streptococcus equi subsp. equi is the causative agent of strangles, a highly contagious disease of the upper respiratory tract of the family Equidae (Timoney, 1993). The disease is initially characterized by nasal discharge and fever, followed by abscess formation in local lymph nodes. In severe cases, infection can become disseminated (bastard strangles) eventually leading to death. Strangles continues to be of major economic importance to the horse industry. However, existing vaccines against strangles seem to afford little protection (Yelle, 1987; Timoney, 1988) and there is a clear need for a more efficacious product.

In Gram-positive cocci, one group of proteins which

Abbreviations: Fg, fibrinogen; $\mathrm{FgBP}$, fibrinogen-binding protein; Fn, fibronectin; IDA, iminodiacetic acid; i.p., intraperitoneal(ly); MALDI-TOF, matrix-assisted laser desorption/ionization time-of-flight; s.c., subcutaneous(ly).

The GenBank accession number for the sequence reported in this paper is AF012927. have received much attention as important virulence factors and as potential protective antigens are those associated with the cell wall. These proteins share a number of structural and functional features, not least of which is their ability to bind host plasma and/or extracellular matrix proteins (reviewed by Kehoe, 1994; Patti et al., 1994; Goward et al., 1993). Amongst the best-studied wall-associated proteins are the $M$ protein family of Streptococcus pyogenes. These dimeric, fibrillar molecules bind several host proteins including fibrinogen (Fg), albumin and $\mathrm{IgG}$, are clearly major antiphagocytic virulence factors, and may have a role in adhesion (Kehoe, 1994; Hasty et al., 1992; Fischetti, 1991). There is also a large body of evidence to suggest that they are protective (Bronze et al., 1992, 1988; Bessen \& Fischetti, 1990; D'Alessandri et al., 1978; Polly et al., 1975). Other protective cell-wall-associated proteins include the fibronectin $(\mathrm{Fn})$-binding protein of staphylococci (Schennings et al., 1993), the pneumococcal PspA protein (AlonsoDeVelasco et al., 1995) and the Streptococcus mutans surface protein antigen I/II (Katz et al., 1993; Okahashi et al., 1989). 
A protective anti-phagocytic $\mathrm{M}$-like protein has been extracted from whole cells of $S$. equi subsp. equi (Timoney, 1993; Timoney \& Mukhtar, 1993; Boschwitz et al., 1991; Jean-François et al., 1991; Galán \& Timoney, 1988). Several studies have shown that binding of Fg to $S$. equi subsp. equi cells confers resistance to phagocytosis, and Timoney and co-workers have additionally provided evidence that $\mathrm{M}$-like protein may be involved in this binding (Boschwitz \& Timoney, 1994). Here we report on the identification, purification and characterization of a major cell-wall-associated protein, which we have called fibrinogen-binding protein ( $\mathrm{FgBP}$ ), of $S$. equi subsp. equi which binds horse Fg, and provide evidence for its protectively immunogenic potential. We also describe the cloning and sequencing of the gene $(f b p)$ encoding $\mathrm{FgBP}$, and the overexpression in Escherichia coli of an FgBP truncate possessing properties analogous to those of the native protein. During preparation of this manuscript, an independent study by Timoney et al. (1997) detailed the cloning and sequencing of two M-like proteins from S. equi subsp. equi. The relationship of these proteins to our own is discussed.

\section{METHODS}

Bacterial strains, plasmids and growth conditions. The virulent isolate, strain TW, of $S$. equi subsp. equi was obtained from the late Dr Paul Storm (Intervet International BV, The Netherlands). Escherichia coli strains DH5 $\alpha$ (Life Technologies) and XLOLR (Stratagene) together with the plasmids pGEM7 (Promega) and pBK-CMV (Stratagene) were used for subcloning and sequencing. E. coli strains LE392 (Promega)

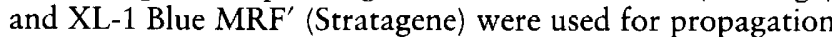
of $\lambda$ phages. E. coli XL-1 Blue (Stratagene) and plasmid pQE30 (Qiagen) was used for expression of the recombinant FgBP. S. equi subsp. equi was grown at $37^{\circ} \mathrm{C}$ on Columbia base agar supplemented with $5 \%(\mathrm{v} / \mathrm{v})$ horse blood or statically overnight in Todd-Hewitt broth supplemented with $0.2 \%$ $(\mathrm{w} / \mathrm{v})$ yeast extract. E. coli strains were grown at $37^{\circ} \mathrm{C}$ in either LB medium or in $2 \times$ YT medium (Lech \& Brent, 1997). Where appropriate, medium was supplemented with ampicillin $\left(100 \mu \mathrm{g} \mathrm{ml}^{-1}\right)$, kanamycin $\left(50 \mu \mathrm{g} \mathrm{ml}^{-1}\right)$, IPTG $(1 \mathrm{mM})$ or $2 \%(\mathrm{w} / \mathrm{v})$ glucose.

S. equi TW cells used in mouse experiments were harvested by centrifugation $\left(16000 \mathrm{~g}, 15 \mathrm{~min}, 4^{\circ} \mathrm{C}\right)$, washed twice in PBS $(0.2$ culture volume), resuspended in PBS $(0.01$ culture volume $)$ and suspensions stored at $-70^{\circ} \mathrm{C}$. On the day of challenge, an aliquot of frozen cells was thawed and diluted appropriately in PBS, and c.f.u. confirmed by plating appropriate dilutions in triplicate onto blood agar plates.

Isolation of cell-wall-associated proteins from envelopes of S. equi. S. equi cells from broth cultures were harvested by centrifugation $\left(16000 \mathrm{~g}, 15 \mathrm{~min}, 4^{\circ} \mathrm{C}\right)$, washed once in $10 \mathrm{mM}$ Tris/HCl buffer $\mathrm{pH} 7 \cdot 2$ (Tris buffer), and finally resuspended in Tris buffer containing DNase $\left(50 \mu \mathrm{g} \mathrm{ml}^{-1}\right)$, RNase $\left(50 \mu \mathrm{g} \mathrm{ml}^{-1}\right)$ and protease inhibitors (2 $\mathrm{mM}$ PMSF, $2 \mathrm{mM}$ benzamidine hydrochloride). Bacteria were then lysed by two passages through a French pressure cell $(221 \mathrm{MPa})$ and unlysed cells were removed by centrifugation $\left(3000 \mathrm{~g}, 10 \mathrm{~min}, 4^{\circ} \mathrm{C}\right)$. Cell envelopes (membranes plus cell walls) were pelleted from the cleared lysate $\left(45000 \mathrm{~g}, 1 \mathrm{~h}, 4^{\circ} \mathrm{C}\right)$ and washed three times in Tris buffer. Cell-wall-associated proteins were isolated using either of two procedures (A or $\mathrm{B}$ ).
Procedure A. Cell envelopes derived from 61 broth culture were resuspended in $36 \mathrm{ml}$ Tris buffer containing $2 \%(\mathrm{w} / \mathrm{v})$ SDS and incubated at $20^{\circ} \mathrm{C}$ for $1 \mathrm{~h}$. Cell wall material (plus associated polymers and proteins), obtained as an SDSinsoluble pellet following centrifugation $\left(45000 \mathrm{~g}, 1 \mathrm{~h}, 20^{\circ} \mathrm{C}\right)$, was subjected to a second SDS-extraction as outlined above. The resultant pellet was washed six times in $10 \mathrm{mM}$ sodium phosphate buffer, $\mathrm{pH} 6.8$ (phosphate buffer) and the purified cell wall material finally resuspended in $9 \mathrm{ml}$ phosphate buffer. Cell-wall-associated proteins were optimally released following extended incubation $(18 \mathrm{~h})$ at $37^{\circ} \mathrm{C}$ with $18000 \mathrm{U}$ mutanolysin in the presence of a cocktail of protease inhibitors (2 mM N ${ }^{\alpha}$-p-tosyl-L-lysine chloromethyl ketone, $2 \mathrm{mM} \mathrm{PMSF}$, and $2 \mathrm{mM}$ benzamidine hydrochloride). Following incubation, the mutanolysin extract was centrifuged $(45000 \mathrm{~g}, 1 \mathrm{~h}$, $\left.4{ }^{\circ} \mathrm{C}\right)$ and released proteins recovered in the supernatant fraction.

Procedure B. Bacterial cell envelopes were washed in phosphate buffer and resuspended directly in $12 \mathrm{ml}$ phosphate buffer containing mutanolysin $(9600 \mathrm{U})$ and the cocktail of protease inhibitors described above. Extraction and harvesting of wall-associated proteins followed that of procedure A.

Affinity purification of FgBP. Cell wall proteins obtained by procedure $B$ described above were incubated with shaking for 2 h at $4{ }^{\circ} \mathrm{C}$ with $7 \mathrm{ml}$ Sepharose $4 \mathrm{~B}$ which had been covalently linked to horse Fg. The Fg-Sepharose 4B slurry was poured into a chromatography column and washed with phosphate buffer until $A_{280}$ approached zero. Glycine $(0 \cdot 2 \mathrm{M}, \mathrm{pH} 2 \cdot 5)$ was used to elute bound FgBP. Fractions, collected into $1 \mathrm{M}$ Tris/ $\mathrm{HCl}(\mathrm{pH} 8 \cdot 0)$, were analysed by SDS-PAGE and those containing FgBP were pooled, dialysed against PBS and lyophilized.

Purification of horse Fg. Contaminating Fn was first removed from horse Fg (Sigma) by adsorption onto a gelatin affinity column (Mosher et al., 1980) prepared by covalently linking gelatin to $\mathrm{CNBr}$-activated Sepharose $4 \mathrm{~B}$. Horse Fg, eluted as unbound material, was then dialysed against $0 \cdot 1 \mathrm{M}$ sodium acetate $(\mathrm{pH} 5 \cdot 0)$, and a precipitate of lipoproteins removed by centrifugation $\left(16000 \mathrm{~g}, 15 \mathrm{~min}, 4^{\circ} \mathrm{C}\right)$. Contaminating horse IgG was then adsorbed onto a protein $G$ affinity column using the procedure recommended by the manufacturer (Pierce). Purified Fg (free of Fn and IgG) eluted as unbound material and was then dialysed against distilled water and lyophilized. The final product was essentially homogeneous as judged by: (a) SDS-PAGE analysis, which confirmed the dominant species to be the three polypeptides chains of reduced horse Fg (see Fig. 1, lane 4); and (b) negative reactions in Western blotting experiments conducted using both anti-horse Fn and antihorse IgG (data not shown).

Biochemical procedures. SDS-PAGE was performed using either a $12.5 \%$ or a $7.5 \%(\mathrm{w} / \mathrm{v})$ polyacrylamide separating gel and a $4.5 \%(\mathrm{w} / \mathrm{v})$ polyacrylamide stacking gel (Laemmli, 1970). Samples were routinely heated for $5 \mathrm{~min}$ at $100^{\circ} \mathrm{C}$ in Laemmli sample buffer (Laemmli, 1970) prior to electrophoresis. Proteins were detected with Coomassie brilliant blue or by silver staining (McVeigh et al., 1988). Molecular masses were determined from the relative mobilities of the following standard molecular mass marker proteins: $\alpha_{2}$-macroglobulin $(340 \mathrm{kDa})$, rabbit myosin $(205 \mathrm{kDa}), \beta$-galactosidase $(116 \mathrm{kDa})$, phosphorylase b $(94 \mathrm{kDa})$, bovine serum albumin $(66.2 \mathrm{kDa})$, catalase $(61 \mathrm{kDa})$, glutamate dehydrogenase $(55.4 \mathrm{kDa})$, fumarase $(48.5 \mathrm{kDa})$, alcohol dehydrogenase $(41 \mathrm{kDa})$, Omp F protein of E. coli $(38 \cdot 3 \mathrm{kDa})$, carbonic anhydrase $(30 \mathrm{kDa})$, chymotrypsinogen $(25 \cdot 1 \mathrm{kDa})$, trypsin inhibitor $(20.1 \mathrm{kDa})$, lysozyme $(14 \cdot 3 \mathrm{kDa})$. Defined peptide 
fragments of FgBP were generated essentially as described by Cleveland et al. (1977). Excised SDS-PAGE slices containing purified FgBP were reelectrophoresed on a second SDS-PAGE gel $(12.5 \%, \mathrm{w} / \mathrm{v}$, polyacrylamide $)$ in the presence of staphylococcal V8 protease. Resultant peptides were then transblotted onto Problot membranes and visualized with amido black. N-terminal amino acid sequence analysis was performed on excised bands using an Applied Biosystems 447 A pulsed-liquid protein sequencer.

Gel filtration chromatography was performed at $4{ }^{\circ} \mathrm{C}$ using Sephacryl S-300 HR, an elution buffer consisting of $20 \mathrm{mM}$ Tris/ $\mathrm{HCl}, 200 \mathrm{mM} \mathrm{NaCl}$ and $0.2 \%(\mathrm{w} / \mathrm{v}) \mathrm{NaN}_{3}$ (pH 7.4) and a flow rate of $5 \mathrm{ml} \mathrm{h}^{-1}$. Molecular masses were estimated from a consideration of the elution profiles of the following standards: ferritin $(450 \mathrm{kDa})$, catalase $(240 \mathrm{kDa})$, aldolase (158 kDa), BSA (68 kDa), hen egg albumin ( $45 \mathrm{kDa})$, chymotrypsinogen $(25 \mathrm{kDa})$ and cytochrome $c(12 \cdot 5 \mathrm{kDa})$.

Protein concentration was estimated by a modification (Dulley \& Grieve, 1975) of the Lowry method using bovine serum albumin as standard. Matrix-assisted laser desorption/ ionization time-of-flight (MALDI-TOF) mass spectrometry was performed by Dr Len C. Packman (Department of Biochemistry, University of Cambridge, UK).

Immunological and affinity procedures. Western immunoblotting was performed as described by Caffery et al. (1988) using $5 \%(\mathrm{w} / \mathrm{v})$ dried skimmed milk as blocking reagent, peroxidase-labelled affinity-purified anti-mouse IgG (Sigma), anti-horse IgG $\mathrm{H}+\mathrm{L}$ (ICN) or anti-rabbit IgG H+L (ICN) as localizing antibodies and 4-chloro-1-naphthol as developing reagent. The procedure for $\mathrm{Fg}$ affinity blotting was similar to that for Western immunoblotting except that $2 \%(\mathrm{w} / \mathrm{v})$ dried skimmed milk was employed and peroxidase-labelled horse Fg $\left(0.1 \mathrm{mg} \mathrm{ml}^{-1}\right.$; prepared as described by Harlow \& Lane, 1988) was used at localizing reagent. The procedure for affinity blotting using recombinant $\mathrm{FgBP}$ as a probe was also performed essentially as described above using $0 \cdot 1 \%(\mathrm{v} / \mathrm{v})$ Tween 20 as blocking agent. Blots were probed with $5 \mu \mathrm{g} \mathrm{FgBP}$ $\mathrm{ml}^{-1}$ and bound FgBP was detected with rabbit anti-FgBP antibodies followed by peroxidase-labelled affinity-purified anti-rabbit IgG, $\mathrm{H}+\mathrm{L}$ antibodies (ICN). Rabbit anti-FgBP antibodies were generated by standard procedures (Owen, 1985).

Test-tube affinity-precipitation experiments were performed using a modification of the immunoprecipitation technique described by Doherty et al. (1986). Fg $(300-600 \mu \mathrm{g})$ in sodium barbital hydrochloride buffer $(\mathrm{pH} \mathrm{8.6)}$ was preincubated for $1 \mathrm{~h}$ at $25^{\circ} \mathrm{C}$ with a cocktail of protease inhibitors and then centrifuged $\left(13000 \mathrm{~g}, 15 \mathrm{~min}, 20^{\circ} \mathrm{C}\right)$. Triton X-100 (final concentration $2 \%, \mathrm{v} / \mathrm{v}$ ) was added to the cleared supernatant. Mutanolysin extracts containing FgBP $(50-100 \mu \mathrm{g})$ were also centrifuged as above to clear any sedimentable material. Solutions containing $\mathrm{Fg}$ and $\mathrm{FgBP}$ were then mixed and incubated for $4 \mathrm{~h}$ at $25^{\circ} \mathrm{C}$. Resultant affinity precipitates were harvested by centrifugation $\left(13000 \mathrm{~g}, 15 \mathrm{~min}, 20^{\circ} \mathrm{C}\right)$, washed twice in $200 \mu \mathrm{l} 0.1 \mathrm{M} \mathrm{NaCl}$ containing $0.5 \%$ (v/v) Triton X100 and finally resuspended in Laemmli sample buffer. Affinity diffusion assays and analysis of excised affinity precipitates were conducted using established techniques (Owen, 1985, 1986).

ELISA to detect anti-FgBP IgG was carried out using standard procedures (Newell et al., 1988). Wells of microtitre plates were coated with $2.5 \mu \mathrm{g}$ purified $\mathrm{FgBP}$ in $50 \mu \mathrm{l} 0 \cdot 1 \mathrm{M}$ sodium carbonate buffer ( $\mathrm{pH} 9 \cdot 6)$, blocked in $1 \%(\mathrm{w} / \mathrm{v})$ bovine serum albumin and incubated with serial twofold dilutions of mouse sera prediluted $1: 250$ in blocking solution. A 1:2000 dilution of peroxidase-labelled affinity-purified anti-mouse IgG was used as secondary antibody and 3,3',5,5'-tetramethylbenzidine as substrate.

Mouse protection experiments. All animal experiments were performed in compliance with EC directive $86 / 609 / \mathrm{EC}$ as implemented in Ireland under Statutory Instrument 17/94. Laca mice (8-12 weeks old) were immunized subcutaneously (s.c.) on days 0 and 28 with $50 \mu \mathrm{g}$ purified $\mathrm{FgBP}$ emulsified in a $200 \mu \mathrm{l}$ volume of MPL + S-TDCM Ribi adjuvant (active ingredients monophosphoryl lipid $\mathrm{A}$ and trehalose dimycolate; RIBI Immunochem Research). Control mice were immunized s.c. either with PBS or with RIBI adjuvant emulsified in PBS. On day 34, blood samples $(100-200 \mu l)$ were taken by cardiac puncture from all mice except two of the control group for whom the procedure proved too stressful. All mice were challenged on day 42 by intraperitoneal (i.p.) injection of $1.5 \times 10^{5}$ c.f.u. $S$. equi TW cells in $200 \mu$ volumes of PBS and were monitored for $32 \mathrm{~d}$ post challenge. For humane reasons, mice were killed if they were considered terminally ill with body temperatures below $32^{\circ} \mathrm{C}$.

Isolation of chromosomal, plasmid and bacteriophage DNA. Genomic DNA, isolated from $S$. equi TW by treatment with mutanolysin, lysozyme and Sarkosyl (Yu \& Ferretti, 1989), was extracted twice with hexadecyltrimethylammonium bromide/chloroform followed by stepwise extraction with phenol/chloroform and chloroform/isoamyl alcohol (Wilson, 1997). DNA was finally precipitated with $0 \cdot 6$ vol. 2-propanol, and ethanol-washed pellets were resuspended in $10 \mathrm{mM}$ Tris/ $\mathrm{HCl}$ containing $10 \mathrm{mM}$ EDTA $(\mathrm{pH} 8 \cdot 0)$. Plasmid and phagemid DNA was purified from $E$. coli by a modified alkaline lysis method (Feliciello \& Chinali, 1993) and recombinant $\lambda$ DNA was purified from phage lysates as detailed by Maniatis et al. (1982).

Construction of genomic libraries of $S$. equi subsp. equi TW. Two libraries were made in lambda using Sau3A-digested $S$. equi genomic DNA. The first was made in $\lambda$ GEM11 and involved ligation to the left and right arms of the $\lambda$ GEM11 (precleaved with $\mathrm{XhoI}$ ) and in vitro packaging as outlined by the manufacturer (Promega). The second was made in $\lambda$ ZAP Express, and involved ligation to vector arms (predigested with $B a m \mathrm{HI}$ ) and packaging using Gigapack III Gold packaging extract as described by the manufacturer (Stratagene).

Screening of $S$. equi genomic libraries and isolation of positive subclones. The degenerate oligonucleotide $5^{\prime} \mathrm{CAR}$ AARGCNAARGAYGARCG 3' $(\mathrm{R}=\mathrm{A}+\mathrm{G}, \mathrm{N}=\mathrm{A}+\mathrm{G}+$ $\mathrm{C}+\mathrm{T}, \mathrm{Y}=\mathrm{C}+\mathrm{T}$ ), made from a knowledge of the amino acid sequence QKAKDER of FgBP, was 5' end-labelled with $\left[{ }^{32} \mathrm{P}\right] \mathrm{dATP} . \lambda$ GEM11 recombinant phages were propagated on E. coli LE392 and hybridizations with labelled oligonucleotide were performed at $50^{\circ} \mathrm{C}$ as outlined by O'Reilly et al. (1988). Blots were then washed at $37^{\circ} \mathrm{C}$ for $15 \mathrm{~min}$ in $5 \times$ saline sodium citrate (SSC), for $15 \mathrm{~min}$ in $2 \times \mathrm{SSC}$ and at $42^{\circ} \mathrm{C}$ for $15 \mathrm{~min}$ in $1 \times \mathrm{SSC}$ and positive plaques were detected by autoradiography. One positive reacting plaque ( $\lambda S E 12)$ was identified, resuspended in phage buffer $(20 \mathrm{mM}$ Tris $/ \mathrm{HCl}$, $\mathrm{pH} 7 \cdot 4$, containing $0.1 \mathrm{M} \mathrm{NaCl}$ and $10 \mathrm{mM} \mathrm{MgSO}_{4}$ ) and propagated to homogeneity.

A $1.8 \mathrm{~kb}$ SacI fragment from $\lambda S E 12$ was labelled with digoxigenin by random priming as outlined by the manufacturer (Boehringer Mannheim) and used to screen plaques from the recombinant $\lambda$-ZAP Express library. Hybridizations were carried out at $65^{\circ} \mathrm{C}$ in standard hybridization buffer as described by Boehringer Mannheim. Positive reacting plaques were detected by chemiluminescence and were propagated to homogeneity. The pBK-CMV phagemid vectors, containing the cloned inserts, were excised from the ZAP Express vector using the Exassist interference- 
resistance helper phage and transformed into E. coli XLORL according to the manufacturer's instructions (Stratagene). One recombinant phagemid (termed pFBP700) was chosen for further study.

DNA sequencing. The sequencing strategy involved the generation of plasmid subclones containing overlapping deletions. The nucleotide sequence of template DNA was then determined using the ABI PRISM Dye Terminator Cycle Sequencing Ready Reaction Kit (Perkin Elmer), commercial primers and, where appropriate, specific primers synthesized from a knowledge of established DNA sequence.

Expression and purification of a FgBP truncate. The region of $f b p$ encoding the first 434 amino acids of the mature protein was cloned into $\mathrm{pQE} 30$. The $f b p$ fragment in question was first amplified by PCR under standard conditions using $p f u$ polymerase (Stratagene), S. equi chromosome as template, and 5' CGCGGATCCAACTCTGAGGTTAGTCGTACG 3' and $5^{\prime}$ TTATTGCTTCAAGCGATTGATTTC $3^{\prime}$ as forward and reverse primers, respectively (underlined nucleotides in the above primers correspond to complementary sequences in the $f b p$ gene). The amplified product was digested with $B a m \mathrm{HI}$ and ligated to the vector pQE30 (digested with BamHI and $S m a \mathrm{I})$. The recombinant plasmid was transformed into $E$. coli XL-1 Blue and the positive transformant E. coli MM21 isolated following growth on L-agar supplemented with ampicillin and glucose.

The hexahistidyl-tagged FgBP truncate was purified using metal chelate affinity chromatography as follows. E. coli MM21 was grown in $2 \times$ YT medium, supplemented with glucose, to $\mathrm{OD}_{600} \sim 0 \cdot 9$. Following induction for $3 \mathrm{~h}$ in the presence of $1 \mathrm{mM}$ IPTG, bacterial cells were harvested, washed, resuspended in binding buffer $(20 \mathrm{mM}$ Tris $/ \mathrm{HCl}$, $0.5 \mathrm{M} \mathrm{NaCl}, \mathrm{pH} 7.9$ ) and lysed by passage through a French pressure cell $(221 \mathrm{MPa})$. The lysate was then cleared by centrifugation $\left(45000 \mathrm{~g}, 1 \mathrm{~h}, 4^{\circ} \mathrm{C}\right)$, and the soluble fraction applied to a nickel-iminodiacetic acid (IDA) column which was then washed extensively with binding buffer until the $A_{280}$ of the effluent reached zero. Hexahistidyl-tagged FgBP truncates were recovered using a $0-1 \mathrm{M}$ gradient of imidazole in binding buffer.

\section{RESULTS}

\section{Isolation of cell-wall-associated proteins}

Cell-wall-associated proteins isolated from S. equi TW by mutanolysin digestion of purified wall material (see Methods, procedure A) showed the presence of several protein species following analysis by SDS-PAGE. The most dominant of these had an apparent $M_{\mathrm{r}}$ of 220000 (Fig. 1, lane 2) and will be referred to as the high- $M_{r}$ protein. Other minor proteins of apparent $M_{\mathrm{r}} 94000$, 74000 and 56000 were also detected following mutanolysin digestion (Fig. 1, lane 2). In contrast, negligible amounts of these proteins were released from control undigested cell wall (Fig. 1, lane 3). Furthermore, the dominant high- $M_{\mathrm{r}}$ protein was barely detectable in the SDS-PAGE profile of SDS-solubilized envelopes (Fig. 1, lane 1) but was a prominent feature of envelopes pretreated with mutanolysin (Fig. 2, lane 2). These data provide convincing evidence that these proteins are specifically anchored to the (SDS-insoluble) cell wall.

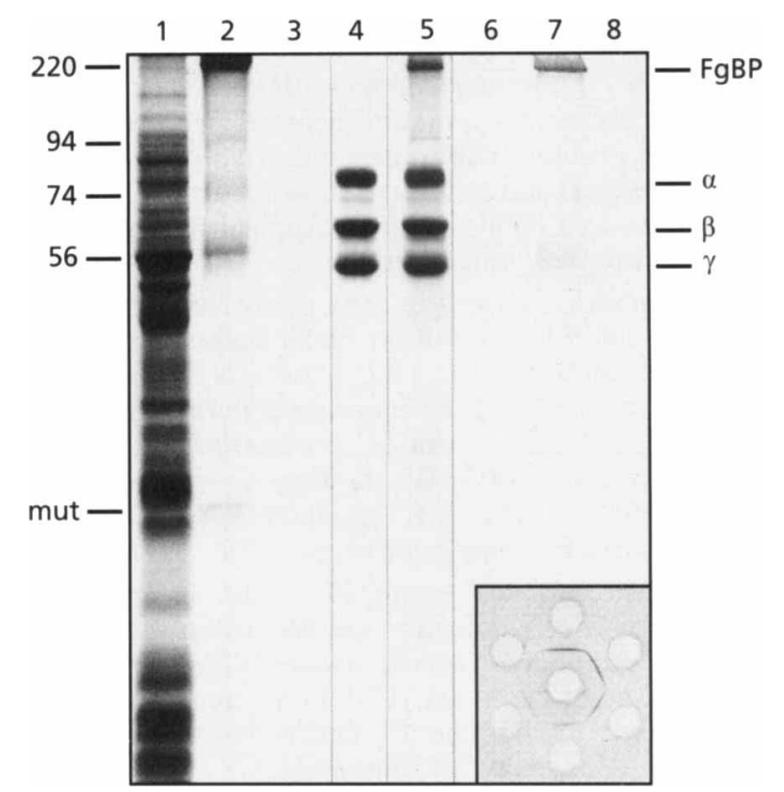

Fig. 1. SDS-PAGE and Fg-affinity blot analysis (main panel) and Fg-affinity diffusion analysis (inset, bottom right) of proteins released from purified cell walls of $S$. equi TW following treatment with mutanolysin. Samples were analysed by SDSPAGE using $12.5 \%(\mathrm{w} / \mathrm{v})$ polyacrylamide separating gels. Lanes: $1,2 \%(w / v)$ SDS extract of cell envelopes; 2 , supernatant fraction from purified cell walls following incubation with mutanolysin; 3, supernatant fraction from purified cell walls incubated in the absence of mutanolysin; 4 , horse $\mathrm{Fg} ; 5$, washed affinity precipitate obtained following incubation of horse $\mathrm{Fg}$ (see lane 4) with mutanolysin extracts (see lane 2). Lanes 1-5 were stained with Coomassie brilliant blue. Lanes 6-8 represent lanes 1-3 electrotransferred onto nitrocellulose and probed with horseradish-peroxidase-conjugated horse $\mathrm{Fg}$. Positions and molecular masses (in $\mathrm{kDa}$ ) of mutanolysinextracted proteins and of mutanolysin (mut) are indicated at the left. The positions of the high- $M_{\mathrm{r}}$ Fg-reacting protein (FgBP) and of the three polypeptides chains $(\alpha, \beta$, and $\gamma)$ of $\mathrm{Fg}$ are indicated to the right. The inset (bottom right) shows agarose affinity diffusion assays conducted with mutanolysin extracts (centre well) and doubling dilutions of horse Fg (clockwise from top well).

\section{Fg binding}

Several lines of evidence suggest that the high- $M_{\mathrm{r}}$ protein binds horse Fg. Firstly, a single precipitate was clearly demonstrated following affinity diffusion experiments conducted with horse Fg and either mutanolysin extracts or purified high- $M_{\mathrm{r}}$ protein (Fig. 1, inset). Secondly, SDS-PAGE analysis of washed affinity precipitates (Owen, 1986) obtained following either affinity diffusion or test-tube affinity precipitation experiments revealed the dominant components to be the high- $M_{\mathrm{r}}$ protein and the three characteristic polypeptides $\left(\alpha, M_{\mathrm{r}} 76000 ; \beta\right.$, $M_{\mathrm{r}} 61000 ; \gamma, M_{\mathrm{r}} 51000$ ) of reduced horse Fg (Fig. 1, lanes 4 and 5 ). In contrast, neither protein formed a precipitate when incubated alone (data not shown). Finally, affinity blotting experiments performed on preparations of cell-wall-associated proteins showed that the high- $M_{r}$ species reacted strongly with labelled 


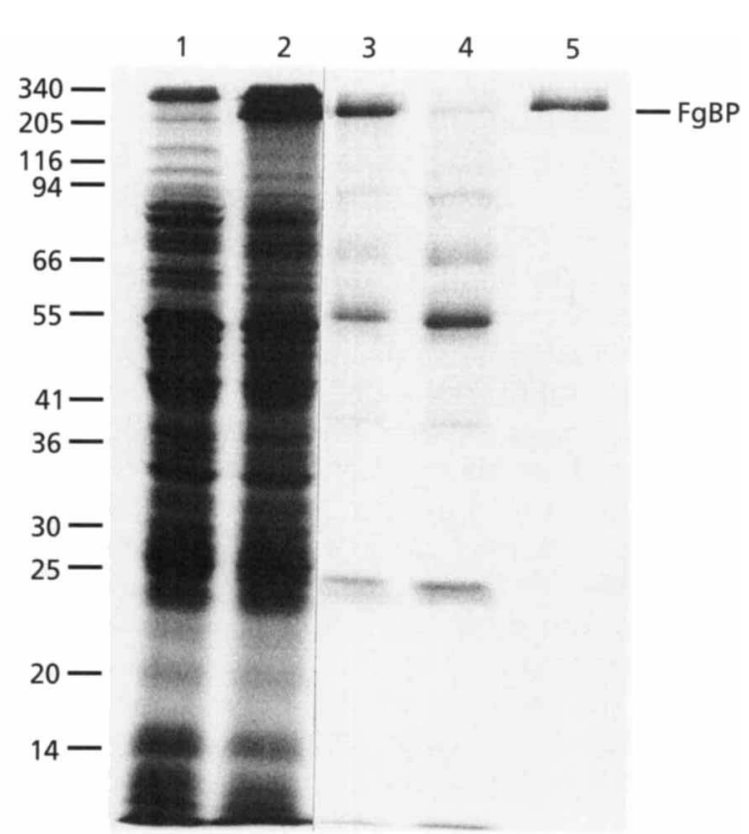

Fig. 2. Purification of the high- $M_{\mathrm{r}}$ FgBP from 5 . equi TW. Samples, analysed by SDS-PAGE using a $12.5 \%$ (w/v) polyacrylamide separating gel, were stained for protein with Coomassie brilliant blue. Lanes: 1 , cell envelope fraction; 2 , cell envelope fraction following incubation with mutanolysin; 3 , supernatant fraction obtained following incubation of cell envelopes with mutanolysin; 4 , proteins eluted unbound from the Fg-affinity column; 5, material purified by Fg-affinity chromatography. The position of the high- $M_{\mathrm{r}} \mathrm{FgBP}$ is indicated. Also indicated to the left of the SDS-PAGE are the positions to which standard molecular mass marker proteins (sizes shown in $\mathrm{kDa}$ ) migrated.

horse Fg (Fig. 1, lanes 6-8). Additional binding experiments indicated that the high- $M_{\mathrm{r}} \mathrm{FgBP}$ bound rabbit Fg but did not appear to bind human Fg, horse Fn, horse IgG or collagen (data not shown).

\section{Purification of the FgBP}

The ability of the high- $M_{r}$ protein to bind Fg facilitated the development of a simple affinity purification procedure for the protein (Fig. 2). To avoid denaturing concentrations of SDS in purification experiments, cell wall proteins were isolated by extracting cell envelopes (i.e. the cytoplasmic membrane and intact cell wall) directly with mutanolysin. This produced a very similar profile of released proteins to that obtained by mutanolysin extraction of SDS-extracted envelopes (compare Fig. 1, lane 2 with Fig. 2, lane 3). Following Fg-affinity chromatography, only the high $-M_{\mathrm{r}}$ FgBP was observed in the low-pH eluate as demonstrated by staining with Coomassie brilliant blue (Fig. 2, lanes 3-5) or silverstaining (data not shown) of SDS-polyacrylamide gels. The yield of pure protein was about $170-340 \mu \mathrm{g} \mathrm{FgBP}$ per litre of cell culture.

SDS-PAGE analysis of the purified protein revealed it to have an apparent $M_{\mathrm{r}}(220000)$ which was unaffected by prolonged boiling (up to $30 \mathrm{~min}$ ) in sample buffer.
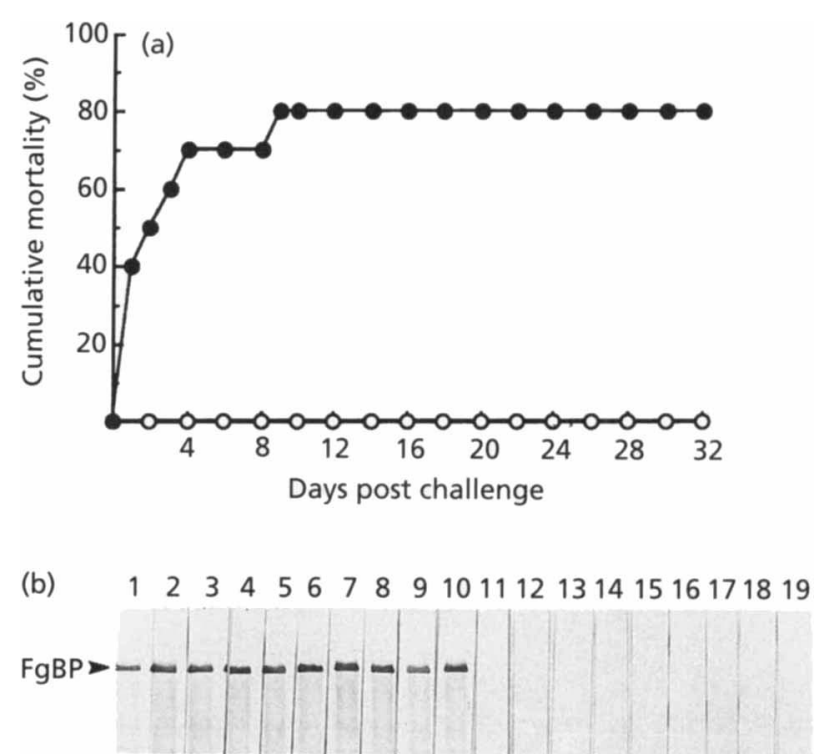

Fig. 3. (a) Protective effect of FgBP against lethal $S$. equi infection in mice. A group of 10 mice were immunized (s.c.) with $50 \mu \mathrm{g}$ affinity-purified FgBP in Ribi adjuvant 42 and $14 \mathrm{~d}$ prior to challenge. Five control mice were immunized with PBS emulsified in Ribi adjuvant only and five mice were immunized with PBS alone. All mice were subsequently challenged (i.p.) with $1.5 \times 10^{5}$ c.f.u. of $S$. equi cells. Controls: $O$, vaccinates. (b) Serum IgG response to FgBP in vaccinated and unvaccinated mice, as monitored by Western immunoblotting. Purified FgBP (lanes 1-19) was analysed by SDS-PAGE using a $12.5 \%(\mathrm{w} / \mathrm{v})$ polyacrylamide separating gel and was electroblotted onto nitrocellulose. Each lane was probed with an individual serum sample taken from a panel of ten vaccinated mice (lanes 1-10) and from a panel of eight unvaccinated (control) mice (lanes 11-18). Lane 19 was probed with anti-mouse IgG antibodies alone. The position of the FgBP is indicated.

Following analysis on $7.5 \%(\mathrm{w} / \mathrm{v})$ polyacrylamide gels (cf. $12.5 \%, \mathrm{w} / \mathrm{v}$, polyacrylamide gels), the protein ran as a more diffuse band (apparent $M_{\mathrm{r}}$ 160000-190000). During gel filtration chromatography on Sephacryl S300 HR the purified protein showed the elution characteristics $\left(V_{\mathrm{e}} / V_{0}=1 \cdot 21\right)$ of a molecule with an estimated $M_{\mathrm{r}}$ ( 550000) somewhat larger than that of ferritin $\left(M_{\mathrm{r}} 450000\right)$. MALDI-TOF mass spectrometry failed to give signals for the protein in the working range of the instrument.

\section{Protection and Western immunoblotting experiments}

The protectively immunogenic potential of the FgBP was tested in a mouse model in which mice, immunized s.c. with purified high- $M_{\mathrm{r}} \mathrm{FgBP}$, were subsequently challenged with a lethal dose of virulent $S$. equi TW. All vaccinates were protected following challenge $(P<$ 0.01 ; see Fig. 3a). Furthermore, at no stage did any vaccinated mouse show clinical signs of illness, nor could $S$. equi be isolated from their peritoneal fluid at the conclusion of the trial (day 32 post-challenge). In contrast, mortality in the control group of mice was $80 \%$ (Fig. 3a), and S. equi was isolated from peritoneal 


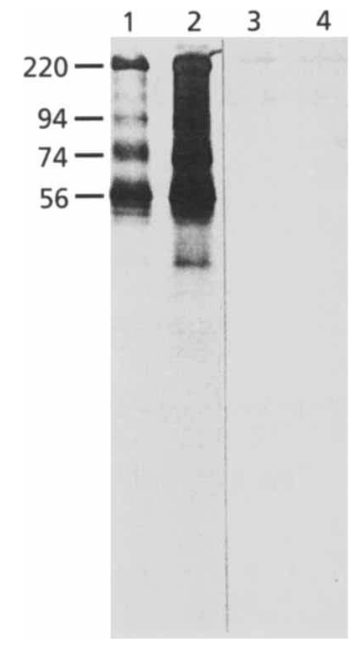

Fig. 4. Serum IgG response to cell-wall-associated proteins of $S$. equi subsp. equi in horses recently recovered from strangles. Supernatant fractions obtained following incubation of cell envelopes with mutanolysin (lanes 1 and 3 ) and mutanolysinextracted cell envelopes ( 2 and 4 ) were analysed by SDS-PAGE using a $12.5 \%(\mathrm{w} / \mathrm{v})$ polyacrylamide separating gel and were electroblotted onto nitrocellulose. Lanes 1 and 2 were probed with serum taken from one of seven horses recently recovered from strangles and lanes 3 and 4 were probed with serum taken from a healthy foal. The profile of reactive proteins was similar for all convalescent horse sera tested. The positions and molecular masses (in $\mathrm{kDa}$ ) of major reacting proteins are indicated at the left of the Western blots.

fluid of all sick mice at the time of death. Western immunoblots conducted using serum taken prior to challenge showed that all mice in the vaccinated group had developed a strong serum IgG response to the high$M_{\mathrm{r}} \mathrm{FgBP}$ whereas mice in the control group had not (Fig. $3 \mathrm{~b})$. This was confirmed by ELISA, where the mean antiFgBP titre of the vaccinates was 32000 versus $<250$ (background levels) for controls.

Evidence that the high- $M_{\mathrm{r}} \mathrm{FgBP}$ is antigenic in horses was obtained in separate Western immunoblot experiments, where it and other wall-associated proteins were shown to react strongly against serum samples taken from a panel of seven horses recently recovered from strangles but only very weakly against serum taken from an uninfected foal (Fig. 4), a phenomenon which may be due to the presence of low levels of maternal antibodies.

\section{Cloning and sequencing of $f b p$}

V8 proteolytic digestion of $\mathrm{FgBP}$ generated at least six peptides of $M_{\mathrm{r}}<14000$ (data not shown). N-terminal amino acid sequence analysis yielded the following two distinct sequences (in single-letter code): (1) NSEVSRTATPRL..., (2) LQKAKDERQALTESFNKTLS.

An S. equi genomic library, constructed in $\lambda$ GEM11, was probed with a degenerate oligonucleotide made from a consideration of amino acid sequence (2) above. One positive clone (2SE12) containing a $15 \mathrm{~kb}$ insert was identified. Subcloning and subsequent DNA sequence analysis of restriction fragments from $\lambda S E 12$ revealed it to contain a truncated $f b p$ gene encoding the first 488 amino acids of the precursor FgBP. A $1.8 \mathrm{~kb}$ SacI fragment from $\lambda S E 12$ containing the promoter region plus the first $1307 \mathrm{bp}$ of the $f b p$ gene was then used as a probe to screen a second genomic library in $\lambda$ ZAP Express. Several positive phagemid clones were identified and one (pFBP700), containing a $3.8 \mathrm{~kb}$ insert in pBK-CMV, was chosen for further experiments. DNA sequence analysis revealed the presence of an open reading frame of 1605 bp encoding the FgBP. It has been reported that cloning of $S$. equi $\mathrm{M}$ proteins can be frustrated by DNA rearrangements (Timoney et al., 1991). However, direct nucleotide sequence analysis of the $f b p$ gene amplified by PCR from the chromosome confirmed the sequence of the above cloned $f b p$ and provided good evidence that no such DNA rearrangements had occurred.

\section{Sequence analysis of $\mathrm{fbp}$ and $\mathrm{FgBP}$}

The $f b p$ open reading frame is preceded by sequences typical of promoter signals $(-10$, tataat; -35 , tgtcat $)$ and ribosome-binding sites (gagagg) and is followed by a sequence resembling a transcriptional terminator, suggesting that the gene product is translated from a monocistronic message. The translated product has the following features (Fig. 5a). The first 36 residues of the deduced amino acid sequence show features characteristic of a signal sequence (von Heijne, 1986). This region shows strong homology (46-62\% identity) with signal sequences of other streptococcal proteins (see Goward et al., 1993). Immediately after the predicted signal cleavage site is a stretch of amino acids corresponding to one of the two sequences (no. 1) obtained by direct amino acid sequencing of V8 fragments of $\mathrm{FgBP}$. The second sequence (no. 2) is located internally in $\mathrm{FgBP}$. The $f b p$ gene encodes a primary translation product of 534 amino acids $\left(M_{\mathrm{r}} 58344\right)$ which is posttranslationally processed to yield a putative mature protein of 498 amino acids (predicted $M_{\mathrm{r}} 54597$ ).

The sequence of the mature protein contains features characteristic of cell wall-associated proteins (see Fig. 5a). Firstly, it possesses a high content of alanine, glutamic acid, leucine and lysine as reported for the $M$ proteins of $S$. pyogenes. In addition, the protein contains two blocks (A, residues 226-272; B, residues 357-405) of degenerate repeated sequences. The $\mathrm{A} 1$ and $\mathrm{A} 2$ repeats are 21 amino acids in length and differ only in one amino acid. A3 is a partial repeat of about five amino acids. The $B$ repeats are 14 amino acids long and are repeated three times. The B1 and B2 repeats possess $64 \%$ identical residues and are separated by a short stretch of seven amino acids. The $\mathrm{B} 2$ and $\mathrm{B} 3$ repeats possess $57 \%$ identical residues. Finally, the C-terminal part of the protein contains features characteristic of cell wall/ membrane-anchoring domains of cell wall proteins. Thus, a short region (482-499) showing a relative 
(a)

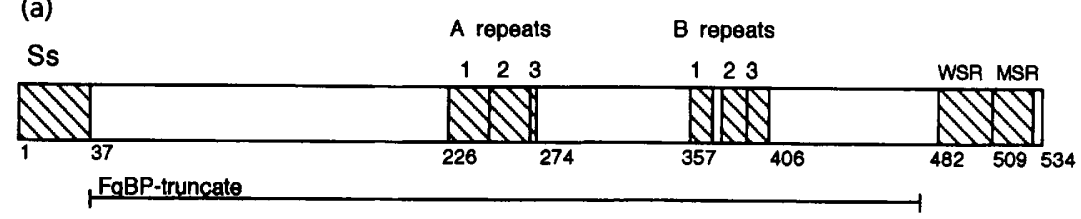

(b)

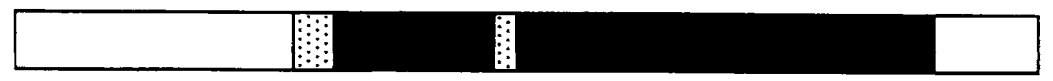

(c)

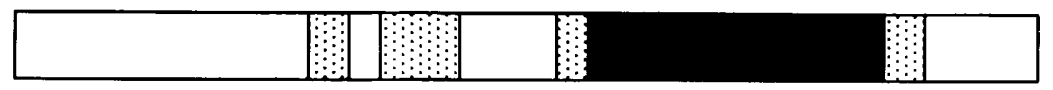

$0-50 \%$
Fig. 5. Schematic representation of the primary and secondary structure of FgBP. (a) The primary structure of $\mathrm{FgBP}$ showing positions of the signal sequence (Ss), the $A$ and $B$ repeats, the wall-spanning region (WSR) and membrane spanning region (MSR). (b) Probability of coiled-coil structure as predicted by the colls web server (http://ulrec3. unil.ch/software/COILS_form.html) using the MITDK matrix, the weighting option and a window of 28 residues. (c) Probability of a coiled-coil dimer as predicted by the MultiCoil web server (http://ostrich.lcs.mit. edu/cgi-bin/multicoil) using a window of 28 residues. The probability ranges applicable to (b) and (c) are given as a key at the bottom of the figure. enrichment of Gly/Pro residues is followed by the consensus LPSTGE motif. This is followed almost directly by 21 hydrophobic amino acids (membranespanning region) and a short tail of five charged amino acid residues. The sequence of the membrane-anchoring domain (from and including LPSTGE) exhibits strong homology (68-74\% residue identity) with corresponding regions in other streptococcal $M$ proteins.

Secondary structure analysis according to the algorithm of Garnier et al. (1978) predicts that $70 \%$ of the FgBP is $\alpha$-helical. More refined structural predictions using the CoIls program (Lupas, 1996; Lupas et al., 1991) suggest that about $60 \%$ of the mature protein possesses an extremely high probability $(95-100 \%)$ of coiled-coil structure, with zero to very low probabilities of such structures in the first 147 residues of the mature protein and at the putative C-terminal wall/membrane anchor region (see Fig. 5b). Analysis by the MULTICoIL program (Wolf et al., 1997) indicates that FgBP most probably assumes a two-stranded coiled-coil structure (Fig. 5c) and that the likelihood of trimer formation is low (data not shown). Similar two-stranded coiled-coil structures have also been proposed for the $M$ proteins from $S$. pyogenes (Nilson et al., 1995).

Computer-assisted searches of existing databases (Altschul et al., 1990) revealed that FgBP showed no significant homology, at the nucleotide and amino acid level (except in the signal sequence and wall/membranespanning regions), to sequences published for most surface proteins from group $C$ streptococci. These include the $\mathrm{M}$-like protein, the Fn-binding protein (FNZ) and the macroglobulin/albumin/IgG-binding (ZAG) protein of $S$. equi subsp. zooepidemicus (Lindmark et al., 1996; Jonsson et al., 1995; Timoney et al., 1995), and the Fg/albumin/IgG-binding protein (FAI) from a horse-derived group C streptococcus (Talay et al., 1996). Nor did the sequence show any homology to the partial sequences published earlier by Timoney and co-workers (Timoney et al., 1991; Galán et al., 1988) for an M-like protein from S. equi. However, comparison of the sequence of $f b p$ with that recently published for SeM of S. equi subsp. equi (Timoney et al.,
1997) reveals near identity - eleven differences in nucleotide sequence translating into six differences in deduced amino acid sequence (at residues 8, 58, 63, 143, 181 and 410 of the FgBP precursor protein).

\section{Expression, purification and properties of an FgBP truncate}

The region of $f b p$ encoding the first 434 amino acids of the mature protein (Fig. 5) was cloned in-frame into the pQE30 expression system. This vector places a hexahistidine affinity tag at the N-terminus of the resultant fusion protein. SDS-PAGE analysis revealed that resultant transformants expressed two major proteins (with apparent $M_{\mathrm{r}}$ values of 200000 and 90000 ), which were not present in lysates of $E$. coli XL-1 Blue harbouring pQE30 alone and which could be purified by $\mathrm{Ni}^{2+}$-IDA affinity chromatography. Of these, the species of higher $M_{\mathrm{r}}$ was the more dominant (Fig. 6). The recombinant truncate, which could be purified in yields of about 3-5 mg per litre of culture, retained many of the properties of native FgBP (Fig. 6, lane 3). Thus, it gave an estimated $M_{\mathrm{r}}$ following gel filtration of $\sim 550000$. In addition, the dominant species observed during SDSPAGE (Fig. 6, lane 4) migrated with apparent $M_{\mathrm{r}}$ values several fold higher than that $\left(M_{\mathrm{r}}\right.$ 49541) anticipated from consideration of sequence. Finally, both major species bound horse Fg (Fig. 6, lane 5), could be purified by Fg affinity chromatography (data not shown), reacted with antiserum to native FgBP (Fig. 6, lane 6) and gave identical profiles to those shown in Fig. 6 (lane 6) when tested in Western immunoblot experiments conducted with sera from vaccinated mice and from various convalescent horses (described in Figs 3 and 4). In the above Western blots, and to a lesser extent in Fg affinity blots, a third reacting band (apparent $M_{r} 49000$ ) could be observed for purified truncate preparations (Fig. 6, lanes 5 and 6). This protein, which may represent the monomeric form of the molecule, was present at low levels since it was barely detectable in SDS-gels stained with Coomassie blue (Fig. 6, lane 4). All three bands observed for the purified recombinant FgBP truncate reacted during Western blotting experiments with anti- 


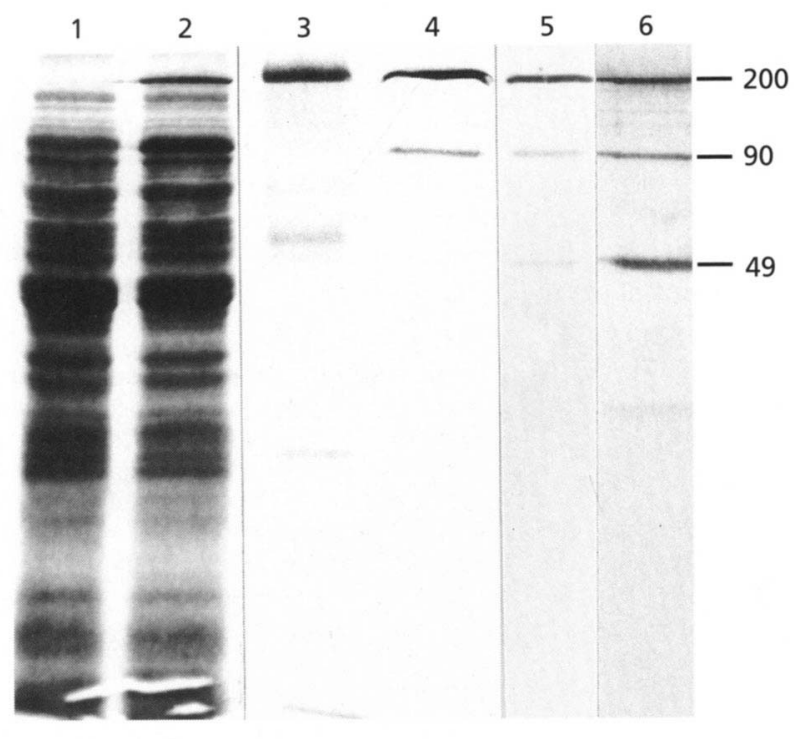

Fig. 6. Hexahistidyl-tagged FgBP truncate analysed by SDSPAGE, Fg-affinity blotting and Western immunoblotting using $12.5 \%(\mathrm{w} / \mathrm{v})$ polyacrylamide separating gels. Lane 1 , soluble fraction of $E$. coli harbouring PQE30; lane 2, soluble fraction of $E$. coli harbouring pQE30-fbp truncate (E. coli MM21); lane 3, mutanolysin extract of $S$. equi cell envelopes; lanes 4-6, proteins from lane 2 selectively eluted from the $\mathrm{Ni}^{2+}-$ IDA column with $200 \mathrm{mM}$ imidazole. Lanes 1-4 were stained for protein with Coomassie brilliant blue. Lanes 5-6 were electrotransferred onto nitrocellulose and probed with horseradish-peroxidase-conjugated horse $\mathrm{Fg}$ (lane 5) or rabbit anti-FgBP antibodies (lane 6). Identical reactions to those shown in lane 6 were observed following probing with either the immune mouse sera (described in Fig. 3) or convalescent horse sera (described in Fig. 4). The position of the $200 \mathrm{kDa}$, $90 \mathrm{kDa}$ and $49 \mathrm{kDa}$ hexahistidyl-tagged $\mathrm{FgBP}$ truncates are indicated on the right.

serum raised to recombinant SeM described by Timoney et al. (1997).

Additional affinity blotting experiments were conducted to determine to which of the three chains of horse Fg (see Fig. 1, lane 4) the FgBP truncate bound. In these experiments, purified fusion protein was used to probe blots of $\mathrm{Fg}$ which had been either subjected to SDSPAGE under reducing conditions or had been spotted directly onto nitrocellulose. Binding to undenatured $\mathrm{Fg}$ but not to reduced $\mathrm{Fg}$ chains was observed (data not shown), implying that binding probably requires some retention by $\mathrm{Fg}$ of native conformation.

\section{DISCUSSION}

Although previous studies (Timoney et al., 1997; Boschwitz \& Timoney, 1994) have suggested that surface proteins from $S$. equi subsp. equi may be involved in binding horse $\mathrm{Fg}$, the present report gives the first description of the dominant molecular species likely to be involved in such reactions. Thus, it is clear from binding experiments and SDS-PAGE analysis of affinity precipitates and of mutanolysin extracts, that the
$(220 \mathrm{kDa})$ high $-M_{\mathrm{r}}$ protein is the major Fg-binding component and that it represents the major cell-wallassociated protein of the organism. Whereas the balance of evidence strongly suggests that the protein binds horse Fg (but not horse Fn, IgG and collagen), the possibility can not be discounted that additional binding to other host components also occurs. We also report for the first time a simple scheme based on the ligandbinding properties of the molecule which facilitates its purification under non-denaturing conditions. Previous attempts to purify such M-like proteins have generally involved denaturing conditions (Timoney et al., 1997; Boschwitz et al., 1991; Timoney \& Trachman, 1985), which have often resulted in preparations enriched in fragments of the native protein.

Timoney et al. (1997) described, for an American isolate (CF32) of S. equi subsp. equi, two distinct M-like proteins (termed SeM and SzPSe) which, on the basis of ELISA assays, appeared to bind equine Fg. Of the two, SeM was the more dominant opsonizing antigen for $S$. equi. It is clear from sequence comparison that $\mathrm{FgBP}$ is essentially identical to SeM, the few differences in amino acid sequence serving to further reinforce the remarkable uniformity previously noted amongst diverse $S$. equi isolates (Timoney et al., 1997; Jorm et al., 1994; Galán \& Timoney, 1988). FgBP shows very little homology with SzPSe and affinity diffusion experiments, SDSPAGE analysis and $\mathrm{N}$-terminal amino acid sequencing of V8 proteolytic fragments have failed to demonstrate the presence of a second Fg-binding component in our own purified preparations. The close similarity in behaviour between our purified high- $M_{r}$ FgBP and a recombinant derivative (see below) also supports this conclusion.

It is clear that the $M_{\mathrm{r}}$ values of the molecule as estimated by SDS-PAGE $(\sim 220000)$ and gel filtration chromatography $(\sim 550000)$ are greatly at variance with that $\left(M_{\mathrm{r}} 54597\right)$ predicted from consideration of gene sequence. Several possible explanations could be invoked to account for these phenomena. These include (a) anomalous migration during SDS-PAGE and gel filtration, (b) formation of heat-stable oligomers, and (c) formation of a high- $M_{\mathrm{r}}$ aggregate composed of the $M_{\mathrm{r}} 54597 \mathrm{FgBP}$ and other protein species and/or cell wall carbohydrate (Boschwitz et al., 1991).

In respect of (a) above, unusual behaviour during SDSPAGE and gel filtration might be anticipated since FgBP is predicted to be a coiled-coil fibrous molecule (Fig. 5), and estimations of $M_{\mathrm{r}}$ in these systems are routinely based on the use of globular protein standards. Certainly, aberrant behaviour of other cell-wall-associated proteins during SDS-PAGE has been observed by several authors (Hartford et al., 1997; Jönsson et al., 1991; Hollingshead et al., 1986; Fahnestock et al., 1986). A relevant example is the $89 \mathrm{kDa}$ Fg-binding protein (clumping factor, ClfA) from Staphylococcus aureus which migrates during SDS-PAGE with an apparent $M_{\mathrm{r}}$ $(>200000)$ more than twice that predicted (Hartford et 
al., 1997). Neither for staphylococcal ClfA nor for $S$. equi $\mathrm{FgBP}$ can this phenomenon be attributed to the presence of the putative wall-spanning domain, since in both cases the ratio of apparent to predicted $M_{\mathrm{r}}$ is largely unaffected for recombinant truncates in which this region has been deleted or reduced in size (Fig. 6; Hartford et al., 1997). In respect of (c) it seems unlikely that the high- $M_{\mathrm{r}} \mathrm{FgBP}$ observed during SDS-PAGE and gel filtration is a complex of more than one molecular species, since a recombinant truncate lacking the putative wall/membrane anchor domain and produced in a heterologous (Gram-negative) expression system behaves in an almost identical fashion to the wild-type product in terms of $M_{\mathrm{r}}$ estimation, Fg binding and seroreactivity. This does not eliminate the possibility that the native FgBP isolated from $S$. equi by mutanolysin digestion contains small residual amounts of (covalently) bound peptidoglycan. A more likely explanation for the high- $M_{\mathrm{r}}$ estimations is the existence of stable homooligomeric complex(es) which only partially dissociate in the presence of hot SDS, i.e. situation (b) above. Certainly, the apparent $M_{\mathrm{r}}$ values and relative amounts of the three immuno/Fg-reactive bands observed for purified recombinant FgBP following SDSPAGE are not incompatible with the presence in a largely tetramer population of low concentrations of monomer and dimer. The existence of homooligomeric structures is also supported by the prediction that coiledcoil dimers (but not trimers) occur with very high probability over an extended region of the molecule. Unfortunately, predictions for higher-stranded structures (i.e. $>3$ ) are compromised at present since available matrices on which such predictions might be based are compiled from comparatively small databases (Lupas, 1996). Given this and the problems in assessing $M_{\mathrm{r}}$ values of fibrous molecules (see above), it is difficult to be definitive in regard to the oligomeric structure of native FgBP. Nevertheless, the results of SDS-PAGE, gel filtration and MALDI-TOF mass spectrometry are collectively not at variance with a dominant species composed of four or more FgBP monomers.

A major difference between our $\mathrm{FgBP}$ and the SeM of Timoney et al. (1997) is the behaviour during SDSPAGE, SeM focusing as a doublet (apparent $M_{\mathrm{r}}$ values 56000 and 58000; Timoney et al., 1997), FgBP as a multimer. Whereas the precise reasons for this discrepancy remain uncertain, it may reflect in part differences in concentrations and in the relative ease of extraction of monomeric and oligomeric forms of the molecule. In our hands, time-course experiments have indicated that maximal extraction of the high- $M_{\mathrm{r}} \mathrm{FgBP}$ is only achieved following prolonged incubation (18 h) of envelopes with mutanolysin in the presence of protease inhibitors, incubation for $1 \mathrm{~h}$ generating 10-20fold less product. It should, however, be noted that mutanolysin extracts and preparations of recombinant FgBP often show the presence of a relatively minor protein species in the predicted monomer $M_{\mathrm{r}}$ range (see Figs 1 and 6). Analogous extracts from the Timoney group are generally prepared by incubation (of whole cells) with mutanolysin for 1 h (Galán \& Timoney, 1987, 1988; Boschwitz et al., 1991) and are analysed by selective immunoenhancing techniques (Western immunoblotting) rather than by direct protein staining. Some of these extracts additionally show the presence of a high- $M_{\mathrm{r}}$ immunoreactive band (estimated $M_{\mathrm{r}}$ 120000-140000) speculated to represent M-like protein bound to cell wall carbohydrate (Timoney \& Mukhtar, 1993; Boschwitz et al., 1991; Galán \& Timoney, 1985). Thus, shorter incubation periods, perhaps dictated in part by a need to minimize protoplast lysis, may facilitate the release of the monomer form, but not of the more dominant multimeric form, the efficient extraction of which requires more extensive degradation of the peptidoglycan layer. Certainly, given the high probability of coiled-coil structure predicted from this study, one might anticipate that oligomeric form(s) would predominate in situ.

The results from experiments with small animals, shown in Fig. 3, represent the first clear demonstration of the protectively immunogenic potential of a defined and purified undenatured protein from $S$. equi. Previous studies in the mouse model have utilized acid extracts of whole cells, culture supernatants, immune horse sera and monoclonal antibodies directed against acidextracted protein (Jean-François et al., 1991; Timoney \& Trachman, 1985). The possibility that protection is elicited by some minor component/contaminant within the high- $M_{\mathrm{r}} \mathrm{FgBP}$ complex seems highly unlikely given that a recombinant truncated FgBP expressed in E. coli reacts with immune sera in an analogous manner to native FgBP. Our observations that (a) the high- $M_{r}$ FgBP is protective in mice (and also in the target species; M. Meehan \& P. Owen, unpublished data), and (b) a recombinant FgBP truncate can be readily purified from E. coli in yields $15-30$-fold higher than that of the native streptococcal product, together with the complementary observations that SeM antiserum is strongly opsonogenic for S. equi (Timoney et al., 1997), give hope that an efficacious vaccine based on this product may soon be a reality.

\section{ACKNOWLEDGEMENTS}

We wish to thank Caroline Woods for valued technical assistance in the animal experiments, Glynis Robinson for performing amino acid sequence analysis, the Irish Equine Centre and John F. Timoney for generous gifts of convalescent horse sera and anti-SeM antibodies, respectively. The work was supported by The National Pharmaceutical Biotechnology Centre, BioResearch Ireland and strategic grant ST/95/112 from Forbairt.

\section{REFERENCES}

AlonsoDeVelasco, E., Verheul, A. F. M., Verhoef, J. \& Snippe, H. (1995). Streptococcus pneumoniae: virulence factors, pathogenesis, and vaccines. Microbiol Rev 59, 591-603.

Altschul, S. F., Gish, W., Miller, W., Myers, E. W. \& Lipman, D. J. (1990). Basic local alignment search tool. J Mol Biol 215, 403-410. Bessen, D. \& Fischetti, V. A. (1990). Synthetic peptide vaccine against mucosal colonization by group A streptococci. I. Pro- 
tection against a heterologous $M$ serotype with shared $C$ repeat region epitopes. J Immunol 145, 1251-1256.

Boschwitz, J. S. \& Timoney, J. F. (1994). Characterization of the antiphagocytic activity of equine fibrinogen for Streptococcus equi subsp. equi. Microb Pathog 17, 121-129.

Boschwitz, J. S., Groschup, M. H. \& Timoney, J. F. (1991). A comparison of different methods of extraction of the M-protein from Streptococcus equi. Cornell Vet 81, 25-36.

Bronze, M. S., McKinsey, D. S., Beachey, E. H. \& Dale, J. B. (1988), Protective immunity evoked by locally administered group A streptococcal vaccines in mice. J Immunol 141, 2767-2770.

Bronze, M. S., Courtney, H. S. \& Dale, J. B. (1992). Epitopes of group A streptococcal $M$ protein that evoke cross-protective local immune responses. J Immunol 148, 888-893.

Caffrey, P., McVeigh, T. \& Owen, P. (1988). Western immunoblotting. In Immunochemical and Molecular Genetic Analysis of Bacterial Pathogens, pp. 255-266. Edited by P. Owen \& T. J. Foster. Amsterdam: Elsevier.

Cleveland, D. W., Fischer, S. G., Kirschner, M. W. \& Laemmli, U. K. (1977). Peptide mapping by limited proteolysis in sodium dodecyl sulfate and analysis by gel electrophoresis. J Biol Chem 252, 1102-1106.

D'Alessandri, R., Plotkin, G., Kluge, R. M., Wittner, M. K., Fox, E. N., Dorfman, A. \& Waldman, R. H. (1978). Protective studies with group A streptococcal $M$ protein vaccine. III. Challenge of volunteers after systemic or intranasal immunization with type 3 or type 12 group A Streptococcus. J Infect Dis 138, 712-718.

Doherty, H., Yamada, H., Caffrey, P. \& Owen, P. (1986). Identification, immunochemical characterization, and purification of a major lipoprotein antigen associated with the inner (cytoplasmic) membrane of Escherichia coli. J Bacteriol 166, 1072-1082.

Dulley, J. R. \& Grieve, P.A. (1975). A simple technique for eliminating interference by detergents in the Lowry method of protein determination. Anal Biochem 64, 136-141.

Fahnestock, S. R., Alexander, P., Nagle, J. \& Filpula, D. (1986). Gene for an immunoglobulin-binding protein from a group $G$ streptococcus. J Bacteriol 167, 870-880.

Feliciello, I. \& Chinali, G. (1993). A modified alkaline lysis method for the preparation of highly purified plasmid DNA from Escherichia coli. Anal Biochem 212, 394-401.

Fischetti, V. A. (1991). Streptococcal M-protein. Sci Am 264, 32-39.

Galán, J. E. \& Timoney, J. F. (1985). Mucosal nasopharyngeal immune responses of horses to protein antigens of Streptococcus equi. Infect Immun 47, 623-628.

Galán, J. E. \& Timoney, J. F. (1987). Molecular analysis of the M protein of Streptococcus equi and cloning and expression of the $M$ protein gene in Escherichia coli. Infect Immun 55, 3181-3187.

Galán, J. E. \& Timoney, J. F. (1988). Immunologic and genetic comparison of Streptococcus equi isolates from the United States and Europe. J Clin Microbiol 26, 1142-1146.

Galán, J. E., Timoney, J. F. \& Curtiss, R., III (1988). Expression and localization of the Streptococcus equi $\mathrm{M}$ protein in Escherichia coli and Salmonella typhimurium. Equine Infect Dis 5, 34-40.

Garnier, J., Osguthorpe, D. J. \& Robson, B. (1978). Analysis of the accuracy and implications of simple methods for predicting the secondary structure of globular proteins. J Mol Biol 120, 97-120.

Goward, C. R., Scawen, M. D., Murphy, J. P. \& Atkinson, T. (1993). Molecular evolution of bacterial cell-surface proteins. Trends Biochem Sci 18, 136-140.
Harlow, E. \& Lane, D. (1988). Labeling antibodies. In Antibodies: a Laboratory Manual, pp. 319-358. Cold Spring Harbor, NY: Cold Spring Harbor Laboratory.

Hartford, O., Francois, P., Vaudaux, P. \& Foster, T. J. (1997). The dipeptide repeat region of the fibrinogen-binding protein (clumping factor) is required for functional expression of the fibrinogen-binding domain on the Staphylococcus aureus cell surface. Mol Microbiol 25, 1065-1076.

Hasty, D. L., Ofek, I., Courtney, H. S. \& Doyle, R. J. (1992). Multiple adhesins of streptococci. Infect Immun 60, 2147-2152. von Heijne, G. (1986). A new method for predicting signal sequence cleavage sites. Nucleic Acids Res 14, 4683-4690.

Hollingshead, S. K., Fischetti, V. A. \& Scott, J. R. (1986). Complete nucleotide sequence of type $6 \mathrm{M}$ protein of the group A Streptococcus : repetitive structure and membrane anchor. J Biol Chem 261, 1677-1686.

Jean-François, M. J. B., Poskitt, D. C., Turnbull, S. J., MacDonald, L. M. \& Yasmeen, D. (1991). Protection against Streptococcus equi infection by monoclonal antibodies against an M-like protein. $J$ Gen Microbiol 137, 2125-2133.

Jonsson, H., Lindmark, H. \& Guss, B. (1995). A protein G-related cell surface protein in Streptococcus zooepidemicus. Infect Immun 63, 2968-2975.

Jönsson, K., Signäs, C., Müller, H.-P. \& Lindberg, M. (1991). Two different genes encode fibronectin binding proteins in Staphylococcus aureus: the complete nucleotide sequence and characterization of the second gene. Eur J Biochem 202, 1041-1048.

Jorm, L. R., Love, D. N., Bailey, G. D., McKay, G. M. \& Briscoe, D. A. (1994). Genetic structure of populations of $\beta$-haemolytic Lancefield group $\mathrm{C}$ streptococci from horses and their association with disease. Res Vet Sci 57, 292-299.

Katz, J., Harmon, C. C., Buckner, G. P., Richardson, G. J., Russell, M. W. \& Michalek, S. M. (1993). Protective salivary immunoglobulin A responses against Streptococcus mutans infection after intranasal immunization with $S$. mutans antigen I/II coupled to the B subunit of cholera toxin. Infect Immun 61, 1964-1971.

Kehoe, M. A. (1994). Cell-wall-associated proteins in Grampositive bacteria. In New Comprehensive Biochemistry, vol 27, Bacterial Cell Wall, pp. 217-261. Edited by J.-M. Ghuysen \& R. Hakenbeck. Amsterdam: Elsevier.

Laemmli, U. K. (1970). Cleavage of structural proteins during the assembly of the head of bacteriophage T4. Nature 227, 680-685.

Lech, K. \& Brent, R. (1997). Media preparation and bacteriological tools. In Current Protocols in Molecular Biology, pp. 1.1.1-1.1.6. Edited by F. M. Ausubel and others. New York: Wiley.

Lindmark, H., Jacobsson, K., Frykberg, L. \& Guss, B. (1996). Fibronectin-binding protein of Streptococcus equi subsp. zooepidemicus. Infect Immun 64, 3993-3999.

Lupas, A. (1996). Prediction and analysis of coiled-coil structures. Methods Enzymol 266, 513-525.

Lupas, A., Van Dyke, M. \& Stock, J. (1991). Predicting coiled coils from protein sequences. Science 252, 1162-1164.

McVeigh, T., Caffrey, P. \& Owen, P. (1988). Silver staining of proteins and lipopolysaccharides in SDS-polyacrylamide gels. In Immunochemical and Molecular Genetic Analysis of Bacterial Pathogens, pp. 267-279. Edited by P. Owen \& T. J. Foster. Amsterdam: Elsevier.

Maniatis, T., Fritsch, E. F. \& Sambrook, J. (1982). Extraction of bacteriophage $\lambda$ DNA. In Molecular Cloning: a Laboratory Manual. Cold Spring Harbor, NY: Cold Spring Harbor Laboratory.

Mosher, D. F., Schad, P. E. \& Vann, J. M. (1980). Cross-linking of 
collagen and fibronectin by factor XIIIa. Localization of participating glutaminyl residues to a tryptic fragment of fibronectin. J Biol Chem 255, 1181-1188.

Newell, D. G., McBride, B. W. \& Clark, S. A. (1988). Enzyme-linked immunosorbent assay for soluble antigens. In Making Monoclonals: a Practical Beginners Guide to the Production and Characterization of Monoclonal Antibodies against Bacteria and Viruses, pp. 37-39. Colindale, UK: Public Health Laboratory Service.

Nilson, B. H. K., Frick, I.-M., Åkesson, P., Forsén, S., Björck, L., Åkerström, B. \& Wikström, M. (1995). Structure and stability of protein $\mathrm{H}$ and the M1 protein from Streptococcus pyogenes. Implications for other surface proteins of $\mathrm{Gram}$-positive bacteria. Biochemistry 34, 13688-13698.

Okahashi, N., Sasakawa, C., Yoshikawa, M., Hamada, S. \& Koga, T. (1989). Molecular characterization of a surface protein antigen from serotype c Streptococcus mutans, implicated in dental caries. Mol Microbiol 3, 673-678.

O'Reilly, M., O'Toole, P. W. \& Foster, T. J. (1988). Screening lambda libraries and detection of recombinants. In Immunochemical and Molecular Genetic Analysis of Bacterial Pathogens, pp. 187-197. Edited by P. Owen \& T. J. Foster. Amsterdam: Elsevier.

Owen, P. (1985). Crossed immunoelectrophoresis in the study of outer membrane antigens. In Enterobacterial Surface Antigens: Methods for Molecular Characterization, pp. 207-242. Edited by T. K. Korhonen, E. A. Dawes \& P. H. Mäkelä. Amsterdam: Elsevier.

Owen, P. (1986). An improved procedure for polypeptide analysis of radiolabeled antigens resolved by crossed immunoelectrophoresis and its application to the study of inner and outer membranes of Escherichia coli. Electrophoresis 7, 19-28.

Patti, J. M., Allen, B. L., McGavin, M. J. \& Hő̈k, M. (1994). MSCRAMM-mediated adherence of microorganisms to host tissues. Annu Rev Microbiol 45, 585-617.

Polly, S. M., Waldman, R. H., High, P., Wittner, M. K., Dorfman, A. \& Fox, E. N. (1975). Protective studies with a group A streptococcal $M$ protein vaccine. II. Challenge of volunteers after local immunization in the upper respiratory tract. $J$ Infect Dis 131, 217-224.

Schennings, T., Heimdahl, A., Coster, K. \& Flock, J.-I. (1993). Immunization with fibronectin binding protein from Staphyl- ococcus aureus protects against experimental endocarditis in rats. Microb Pathog 15, 227-236.

Talay, S. R., Grammel, M. P. \& Chhatwal, G. S. (1996). Structure of a group $\mathrm{C}$ streptococcal protein that binds to fibrinogen, albumin and immunoglobulin $G$ via overlapping modules. Biochem J 315, 577-582.

Timoney, J. F. (1988). Protecting against 'strangles': a contemporary view. Equine Vet J 20, 392-394.

Timoney, J. F. (1993). Strangles. Vet Clin North Am Equine Pract 9, 365-374.

Timoney, J. F. \& Mukhtar, M. M. (1993). The protective M proteins of the equine group C streptococci. Vet Microbiol 37, 389-395.

Timoney, J. F. \& Trachman, J. (1985). Immunologically reactive proteins of Streptococcus equi. Infect Immun 48, 29-34.

Timoney, J. F. , Mukhtar, M., Galán, J. \& Ding, J. (1991). M proteins of the equine group $\mathrm{C}$ streptococci. In Genetics and Molecular Biology of Streptococci, Lactococci, and Enterococci, pp. 160-164. Edited by G. M. Dunny, P. P. Cleary \& L. L. McKay. Washington, DC: American Society for Microbiology.

Timoney, J. F., Walker, J., Zhou, M. \& Ding, J. (1995). Cloning and sequence analysis of a protective $\mathrm{M}$-like protein gene from Streptococcus equi subsp. zooepidemicus. Infect Immun 63, 1440-1445.

Timoney, J. F., Artiushin, S. C. \& Boschwitz, J. S. (1997). Comparison of the sequences and functions of Streptococcus equi Mlike proteins SeM and SzPSe. Infect Immun 65, 3600-3605.

Wilson, K. (1997). Preparation of genomic DNA from bacteria. In Current Protocols in Molecular Biology, pp 2.4.1-2.4.5. Edited by F. M. Ausubel and others. New York: Wiley.

Wolf, E., Kim, P. S. \& Berger, B. (1997). MultiCoil : a program for predicting two- and three-stranded coiled-coils. Protein Sci 6, 1179-1189.

Yelle, M. T. (1987). Clinical aspects of Streptococcus equi infection. Equine Vet J 19, 158-162.

Yu, C.-E. \& Ferretti, J. J. (1989). Molecular epidemiologic analysis of the type A streptococcal exotoxin (erythrogenic toxin) gene (speA) in clinical Streptococcus pyogenes strains. Infect Immun 57, 3715-3719.

Received 14 October 1997; accepted 26 November 1997. 